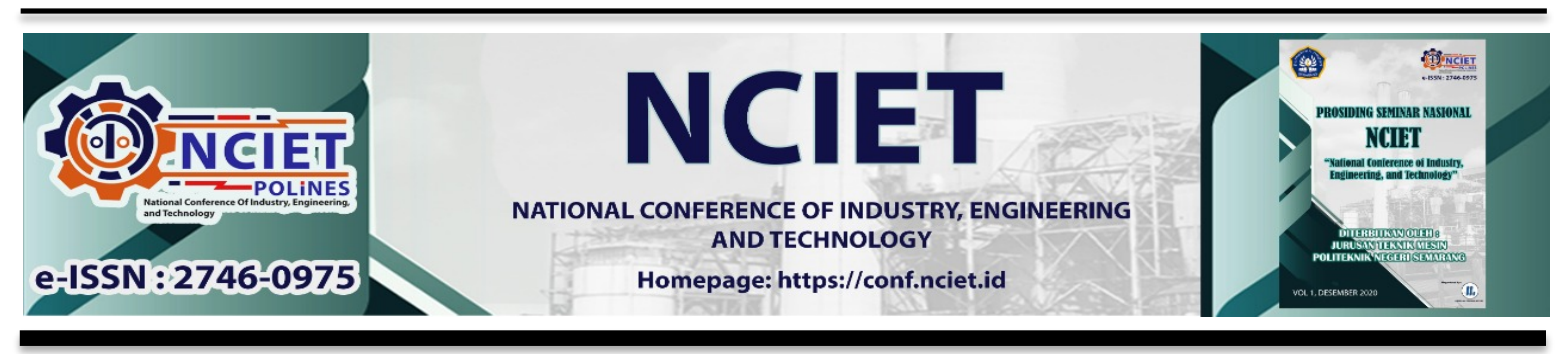

Prosiding Seminar Nasional NCIET Vol.1 (2020) B528-B534

$1^{\text {st }}$ National Conference of Industry, Engineering and Technology 2020,

Semarang, Indonesia.

\title{
SISTEM KONTROL PROPORTIONAL INTEGRAL DERIVATIVE (PID) UNTUK MENGATUR KECEPATAN MOTOR DC MENGGUNAKAN MIKROKONTROLLER
}

\section{Mochamad Denny Surindra*, Wiwik Purwanti Widyaningsih, Margana, Supriyo, Teguh Harjono Mulud}

Jurusan Teknik Mesin, Politeknik Negeri Semarang

J1. Prof. H Soedarto, SH, Tembalang, Semarang, 50275

*E-mail: dennysurindra@polines.ac.id

\begin{abstract}
Abstrak
Motor DC (direct current) adalah peralatan elektromekanik dasar yang berfungsi untuk mengubah tenaga listrik menjadi tenaga mekanik. Untuk mengendalikan motor DC tersebut dapat diaplikasikan Kontroller Proportional yang merupakan salah satu controller konvensional yang mampu mengendalikan motor DC. Paper ini bertujuan membuat pemodelan control proportional untuk mengendalikan motor DC dan hasil respon output dianalisis untuk mengetahui bagaimana respon system dalam mengendalikan motor DC. Parameter motor DC diasumsikan agar memungkinkan untuk membangkitkan torque dari motor DC. Nilai Kp yang diaplikasikan sangat mempengaruhi besarnya nilai error yang muncul. Dimana semakin besar nilai Kp membuat nilai offset semakin kecil, walaupun ada harga Kp maksimum.
\end{abstract}

Kata kunci : Respon output, control proportional, Motor DC

\section{PENDAHULUAN}

Pengontrol PID adalah jenis pengontrol yang banyak diaplikasikan dalam control proses industry karena kesederhanaan strukturnya, lebih tahan terhadap gangguan luar serta dapat diterapkan dalam kondisi operasi yang bervariasi (Gene dkk., 2008). Pengontrol PID perlu ditala secara benar yaitu menentukan harga konstanta pengontrol proporsional, integral dan derivatif yang mengoptimalkan kinerja sistem (Nurcahyo 2003). P controller dapat mengurangi rise time, menambah overshoot, dan mengurangi steady state error, I kontroller dapat mengurangi rise time, menambah overshoot, dan mengeliminasi steady state error dan D controller dapat mengurangi overshoot dan mengurangi setting time (Nurcahyo, 2003; Kuo, 2005) . Kendali proporsional, keluaran dari sistem kendali selalu sebanding dengan masukannya. Sinyal keluaran merupakan penguatan dari sinyal kesalahan dengan factor tertentu, faktor penguatan ini merupakan konstanta proporsional dari sistem, yang 
dinyatakan dengan $\mathrm{Kp}$, dengan I ( $\mathrm{p}$ ini rnempunyai tanggapan sistem yang tinggi atau cepat (Kuo, 2005). Kendali Integral, keluaran dari controller ini selalu berubah selama terjadi penyimpangan dan kecepatan perubahan keluaran tersebut sebanding dengan penyimpangan, konstanta dinyatakan dengan $\mathrm{Ki}$, dengan $\mathrm{Ki}$ ini mempunyai sensitivitas yang tinggi, yaitu dengan cara mereduksi kesalahan (error) yang dihasilkan dari sinyal umpanbalik (feedback). Makin besar nilai Ki maka sensitivitas akan semakin tinggi, tetapi waktu yang dibutuhkan untuk mencapai kestabilan lebih cepat, demikian pula sebaliknya. Kendali defferensial (turunan) bekerja berdasarkan laju perubahan simpangan, sehingga jenis kontroler ini selalu digunakan bersama-sama dengan controller proporsional dan integral, konstantanya dinyatakan dengan $\mathrm{Kd}$, dengan $\mathrm{Kd}$ ini mempengaruhi kestabilan dari system, karena aksi kendali ini dapat mereduksi kesalahan (error) (NIse, 2010).

Teknik pengontrolan saklar elektronik dengan komponen Triac menjadi cerdas, maka harus ada sebuah sensor yang mampu membaca arus yang mengalir dan memberitahukan kepada system control utama untuk mengambil tindakan memberi tegangan kepada kaki Gerbang (input sinyal penyulutan) agar membuka saklar elektronik tersebut. Sistem kontol utama dirancang berasal dari mikrokontroller AVR Atmel (Xue dkk., 2010). Mikrokontroller yaitu teknologi semikonduktor dengan kandungan teransistor yang lebih banyak namun hanya membutuhkan ruang yang kecil, dapat digunakan untuk membuat suatu aplikasi. Pada mikrokontroler, program control disimpan dalam ROM yang ukurannya relative lebih besar, sementara RAM digunakan sebagai tempat penyimpanan sementara, termasuk register-register yang digunakan pada Mikrokontroller yang bersangkutan. Salah satu keluarga dari mikokontroller 8bit AVR adalah Mikrokontroller ATMEGA-16 dan mempunyai 3 jenis memori, memori program, memori data, dan memori EEPROM (Rangkuti, 2011). Surindra (2013) telah membuat simulasi dengan menggunakan Matlab untuk memodelkan control PID yang mengendalikan motor DC sehingga dapat mensimulasikan aplikasi controller dengan hasil berbagai respon output, kemudian dengan menentukan nilai parameter yang memungkinkan untuk membangkitkan torque dari motor DC, kemudian hasil respon output dianalisa untuk mengetahui bagaimana respon system dalam mengendalikan motor DC. Tujuan paper ini adalah membuat pemodelan control PID untuk memprediksi performance control kecepatan motor DC. 


\section{METODE PENELITIAN}

Metode perancangan dilakukan dengan menggunakan tahapan sebagai berikut: identifikasi masalah dan analisis, studi literatur, perancangan sistem kontrol yaitu, perakitan sistem hardware dan perakitan sistem software, pengujian terhadap fungsi dari sistem hardware dan sistem software dan tahapan selanjutnya adalah pengujian dengan menggunakan beban (uji kinerja) serta melakukan olah data dan penarikan kesimpulan. Kecepatan putar motor yaitu kecepatan putar sedang untuk memutar bahan cair, viskos ataupun padat yang berkisar antara $200-1750 \mathrm{rpm}$. Memiliki sistem untuk mengendalikan kecepatan putar motor, yaitu mikrokontroler. Mikrokontroler menjadi wadah untuk mengolah dan memberikan instruksi kepada motor berupa sinyal PWM. Sistem kendali PID dibuat dalam bentuk algoritma program (software) yang nantinya diinput kedalam mikrokontroler. Memiliki sistem untuk mengendalikan tegangan yang masuk kedalam motor sehingga kecepatan dapat diatur sesuai yang dibutuhkan. Aktuator SSR digunakan sebagai driver motor untuk mengolah instruksi dari mikrokontroler sebelum sampai ke motor. Penggunaan SSR disesuaikan dengan motor yang digunakan yaitu motor DC, sehigga diperlukan SSR yang dapat mengatur listrik DC dan memiliki kapasitas arus yang besar serta output tegangan 24 Volt untuk kebutuhan motor. SSR dipilih karena lebih mudah untuk didapat, dan harganya lebih murah, serta tidak cepat panas. Memiliki sistem untuk melakukan pembacan terhadap kecepatan motor sebagai feedback dari sistem loop tertutup yang digunakan. Penggunaan sensor untuk pembacaan rpm motor sebaiknya telah menghasilkan keluaran berupa pulsa agar lebih mudah terbaca oleh mikrokontroler.

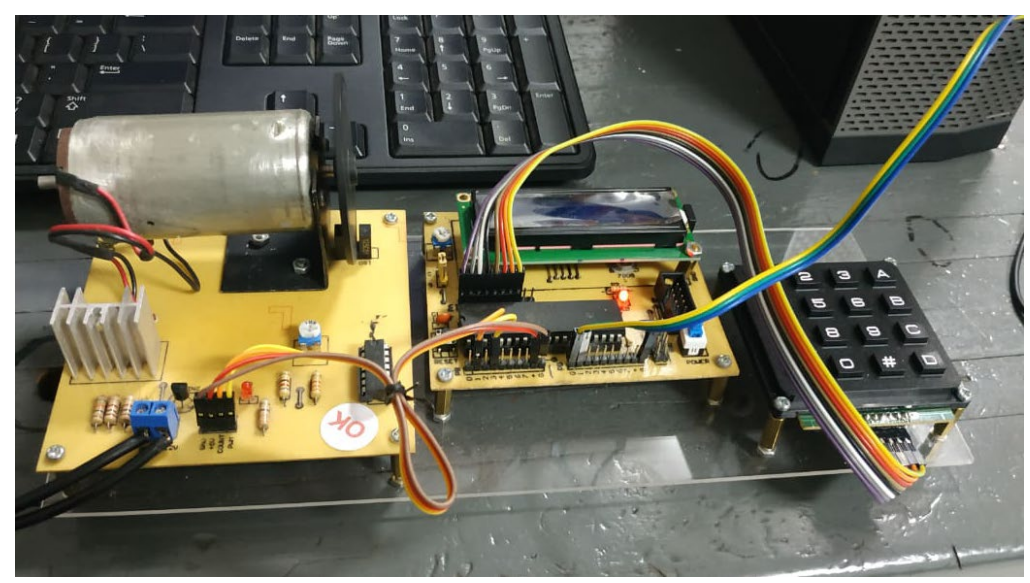

Gambar 1. Hardware PID kontroller 
Adapun spesifikasi controller berbasis mikrokontroler AVR ATmega8535, power supply controller : $+12 \mathrm{~V}$ (dilengkapi regulator 5 Volt), Motor DC $12 \mathrm{~V}$, kecepatan motor : 2000 rpm (no load), sensor kecepatan : opto coupler, Keypad $4 \times 4$ dan LCD $2 \times 16$. Sebagai controllernya mikrokontroler AVR (ATmega8535). Sinyal PWM dibuat oleh mikrokontroler untuk selanjutnya dipakai mengendalikan kecepatan motor. Setelah di-driver dulu tentunya. Dilengkapi dengan sensor kecepatan putaran motor (rpm). Keypad dipakai untuk men-seting parameter kendali PID : Kp, Ki, Kd serta SetPoint (SP).

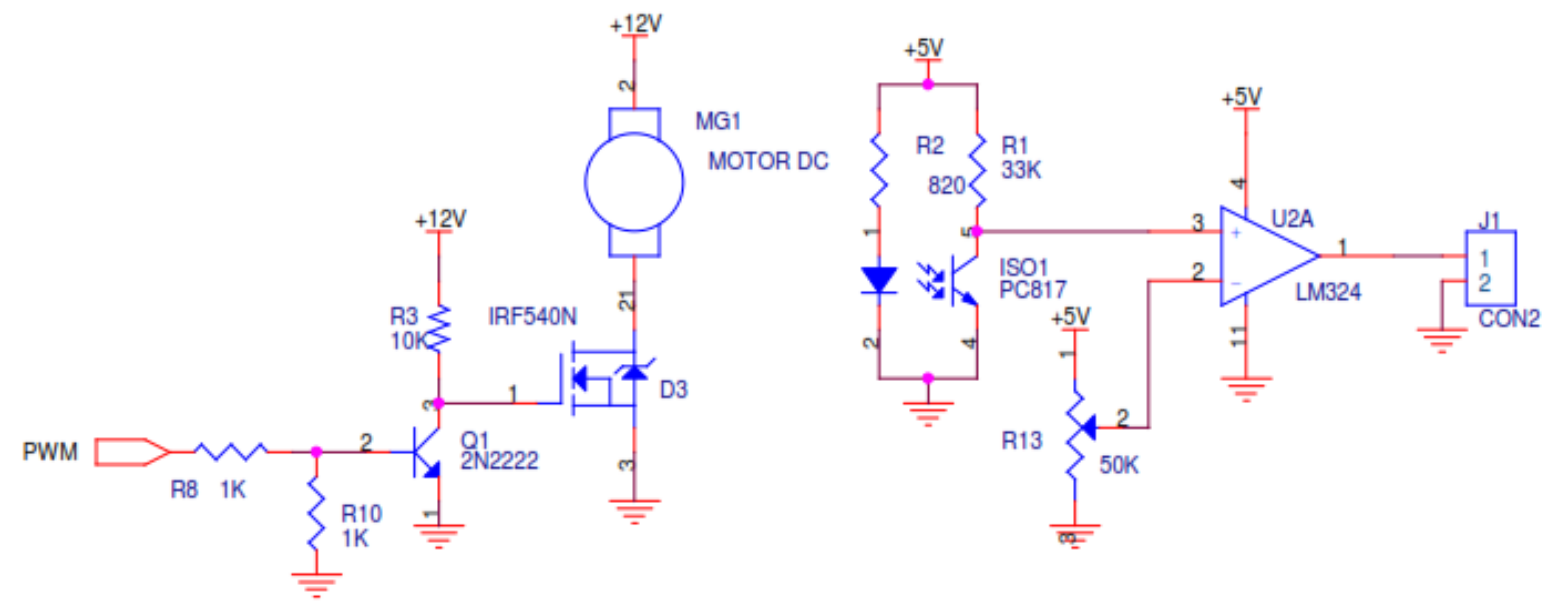

Gambar 2. Skematik Control Motor DC

\section{HASIL DAN PEMBAHASAN}

Hail respon pengaturan dari transfer function yang ada didapatkan seperti dalam Gambar 3, dimana respon tidak mampu mencapai setting point yang ditargetkan.

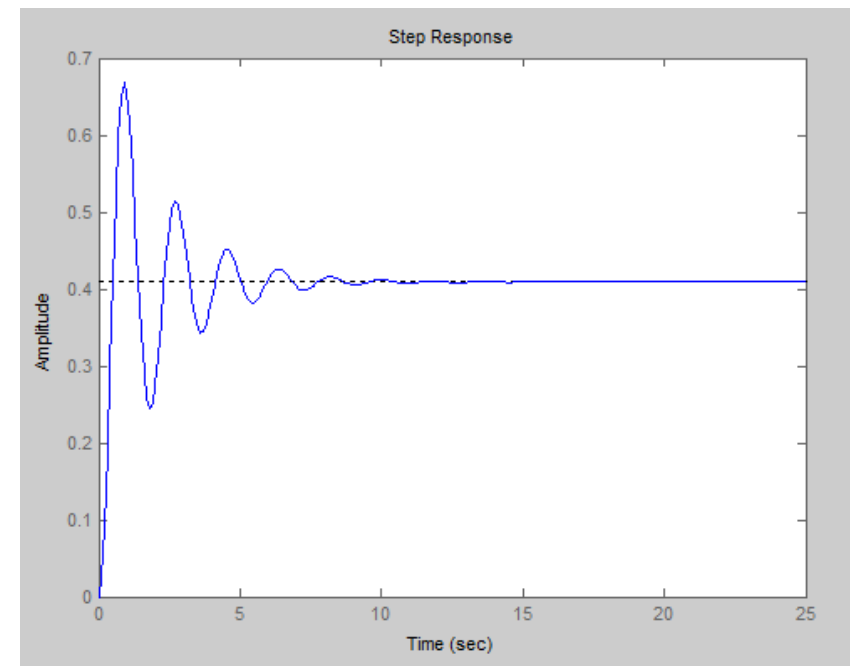

Gambar 3. Tanpa control pengaturan 
Rise time bergerak cepat mencapai puncak sekitar 0,68 meskipun tidak mencapai target yang diinginkan dalam detik yang pertama. Settling time berlangsung sampai sekitar 6 detik, dengan rentang waktu 0 sampai 6 detik terjadi osilasi.

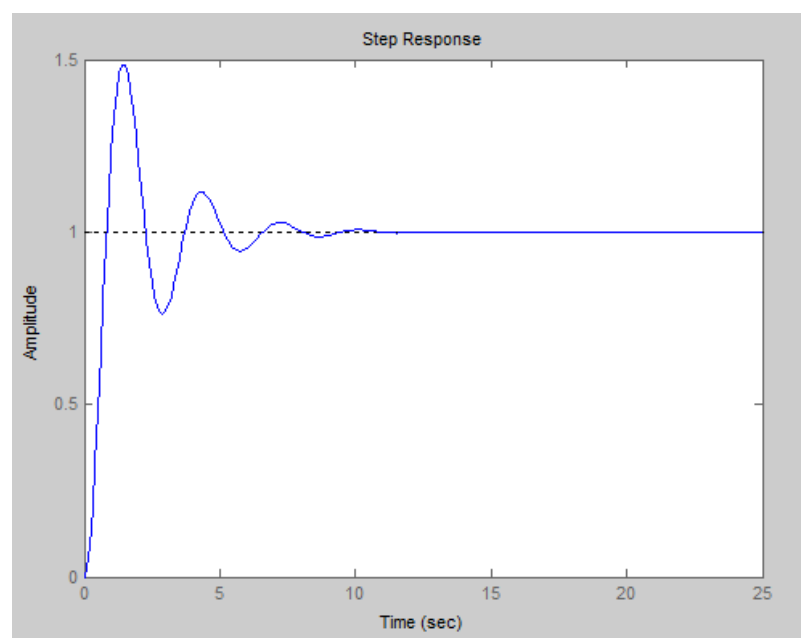

Gambar 4. Kontrol Proporsional dengan $\mathrm{Kp}=5$.

Dengan menambahkan control proporsional Kp sebesar 5 point seperti yang terlihat dalam gambar 4 mencapai rise time sebesar sekitar 2 detik dengan amplitude sebesar 1,5, sedangkan settling time mencapai 6,5 detik. Waktu tunda yang dapat dicatat sebesar 0,7 detik dan respon mencapai maksimum overshoot mencapai 1,48 dalam waktu 1,9,detik.

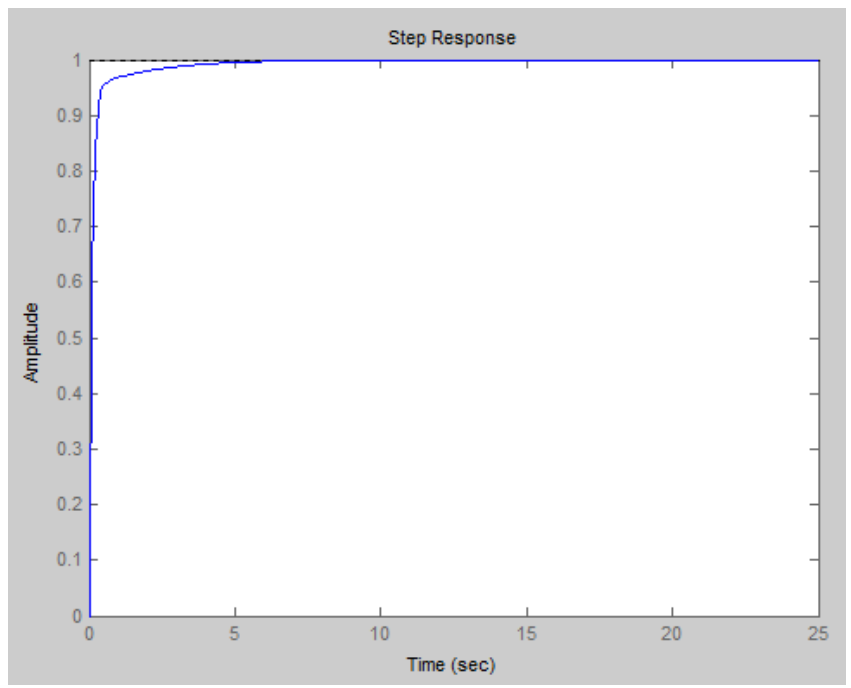

Gambar 5. Kontrol Proporsional dan derivative dengan $\mathrm{Kp}=5$ dan $\mathrm{Kd}=10$ 
Respon system ini menambahkan konstanta derivative $\mathrm{Kp}=5$ dan perhitungan sebesar $\mathrm{Kd}=10$, maka maka $G(s)=\frac{10 s+5}{2 s^{2}+11 s+5}$, kemudian waktu tampilan diatur $\mathrm{t}=15$ detik dengan pencacah waktu 0,1 detik singga grafik didapatkan seperti dalam gambar 5 . Kenaikan rise time sangat cepat dan tidak terjadi maksimum over shoot, sehingga respon untuk mencapai nilai yang disetting cukup lambat jika dibandingkan dari control sebelumnya dan simtem mulai stabil pada 7 detik kemudian. Tidak terjadi osilasi pada system ini dan settling time pada detik ke 3 .

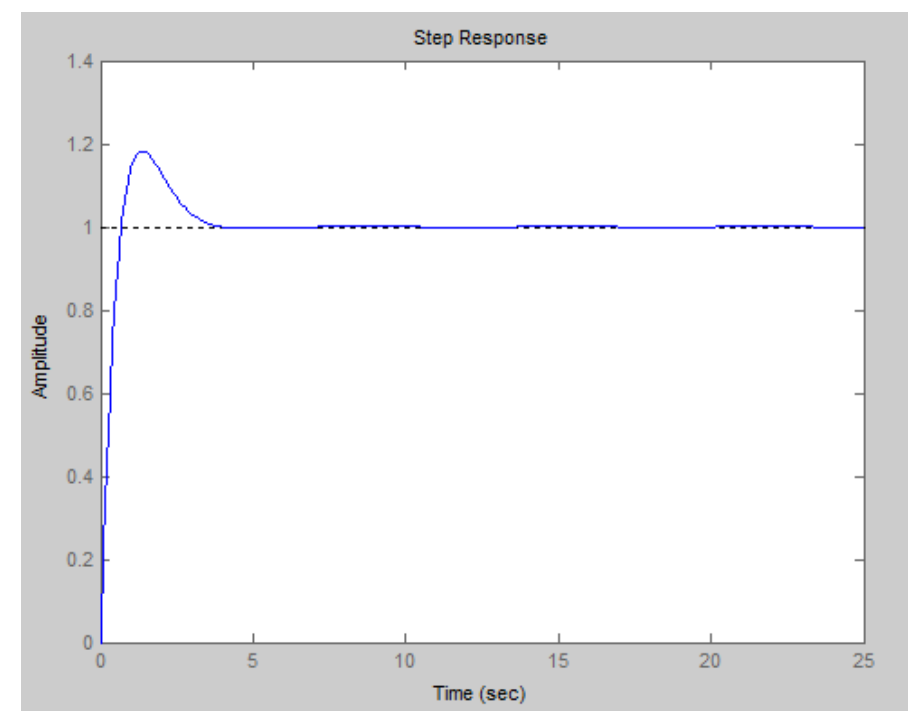

Gambar 6. Kontrol Proportional, Integral dan Derivatif dengan $\mathrm{Kp}=5$.

Respon system pada gambar 6 dengan menggunakan control PID dengan besarnya $\mathrm{Kp}=5$ maka $G(s)=\frac{5 s+5}{2 s^{2}+5 s+5}$ kemudian dengan waktu pencacah sebesar 15 detik dengan pencacah waktu 0,1 detik dengan ploting grafik seperti dalam gambar 6 . Waktu yang dibutuhkan untuk rise time adalah 2,2 detik untuk mencapai maksimum overshoot yang tercatat sebesar 1,18, sedangkan harga delai time dengan ukura 0,5 dari waktu yang dibutuhkan untuk mencapai maksimum over shoot adalah sebesar 0,2 detik. Sistem memasuki settling time pada waktu 3,5 detik dan mulai stabil pada waktu 4 detik.

\section{KESIMPULAN}

Sistem tanpa control kece[patan rise time 0,68 deti sedangkan settling time 6 detik, dengan rentang waktu 0 sampai 6 detik terjadi osilasi. Respon system yang terbaik dengan control 
PID dengan besarnya $\mathrm{Kp}=5$, waktu rise time adalah 2,2 detik untuk maksimum overshoot sebesar 1,18, sedangkan delai time 0,2 detik. Settling time pada waktu 3,5 detik dan mulai stabil pada waktu 4 detik.

\section{DAFTAR PUSTAKA}

Gene, F.F., Powell, J.D. and Naeini, AB. 2008. Feedback control of dynamic system $4^{\text {rd }}$. Addison-Wesley.

Nurcahyo, S., 2003, AVR Atmel Object. Pradnya Paramita, Jakarta.

Kuo, C.B., 2005 Automatic Control System $7^{\text {rd }}$. Prentice Hall.

NIse, N.S. 2010. Control System Engineering $2^{\text {nd }}$ edition, Redwood City, California: The Benjamin/Cummings Publishing Company, Inc.

Xue., D, Chen Y.Q. and Atherton D.P. 2010. Linear Feedback Control Analysis and Design with MATLAB Society for Industrial and Applied Mathematics Philadelphia.

Rangkuti, S. 2011. Mikrokontroler Amet AVR Simulasi dan Praktek menggunakan ISIS Proteus dan Code Vision AVR, Informatika.

Surindra, MD, Analisis Respon Output dari Pemodelan Kontrol Proporsional Intergral pada Aktuator Motor DC. Eksergi Jurnal Teknik Energi 2013, Mei Vol.9,No.2 hal. 43-46, 